\title{
Original article (short paper) \\ Effect of combined aerobic and resistance training in body composition of obese postmenopausal women
}

\author{
Fabrício E. Rossi \\ São Paulo State University, Rio Claro, SP, Brazil \\ Camila Buonani \\ Juliana Viezel \\ Eduardo P. da Silva \\ São Paulo State University, Presidente Prudente, SP, Brazil \\ Tiego A. Diniz \\ Vanessa R. dos Santos \\ São Paulo State University, Rio Claro, SP, Brazil \\ Rômulo A. Fernandes \\ Ismael F. Freitas Junior \\ São Paulo State University, Presidente Prudente, SP, Brazil
}

\begin{abstract}
The aim of this study was to investigate the effects of a 16-week program of combined aerobic and resistance training on the body composition of postmenopausal women who are obese. The participants were divided into two groups: training group (TG, $n=37)$ and non-trained control group (CG, $n=18)$. The trunk fat, fat mass, percentage of fat mass and fat-free mass were estimated using DXA. Three nonconsecutive 24-hour dietary recalls were conducted. The training protocol consisted of 50 minutes of resistance training followed by 30 minutes of aerobic training. After the 16-week training program, differences were observed in trunk fat $(\mathrm{CG}=0.064 \times \mathrm{TG}=-0.571 \mathrm{Kg} ; p$-value $=.020)$, fat mass $(\mathrm{CG}=-0.088 \times \mathrm{TG}=-1.037 \mathrm{Kg} ; p$-value $=.020)$ and fat-free mass $(\mathrm{CG}=-0.388 \times \mathrm{TG}=1.049 \mathrm{Kg} ; p=.001)$. Therefore, a 16-week program of systematic combined aerobic and resistance training in obese postmenopausal women was effective in improving fat-free mass and decreasing both whole and abdominal adiposity.
\end{abstract}

Keywords: obesity, endurance training, DXA, climacteric

Resumo - "Efeito do treinamento aeróbico e resistência combinada na composição corporal de mulheres obesas pós-menopáusicas." O objetivo deste estudo foi investigar os efeitos de 16 semanas de treinamento aeróbio e resistido combinados na composição corporal de mulheres na pós-menopausa. As participantes foram divididas em dois grupos: grupo treinamento (GT, $n=37$ ) e grupo controle (GC, $n=18$ ). A gordura de tronco, massa gorda, percentual de gordura e massa livre de gordura foram estimadas pelo DEXA. O recordatório alimentar de $24 \mathrm{~h}$ foi realizado três dias não consecutivos para controle alimentar. $\mathrm{O}$ protocolo de treinamento consistiu de 50 minutos de treinamento resistido seguido por 30 minutos de treinamento aeróbio. Após 16 semanas de treinamento diferenças foram observadas na gordura de tronco $(\mathrm{GC}=0,064$ $\mathrm{x} \mathrm{GT}=-0,571 \mathrm{Kg} ; p$-valor $=0,020)$, massa gorda $(\mathrm{GC}=-0,088 \times \mathrm{GT}=-1,037 \mathrm{Kg} ; p$-valor $=0,020)$ e massa livre de gordura $(\mathrm{GC}=-0,388 \times \mathrm{GT}=1,049 \mathrm{Kg} ; p$-valor=0,001). Assim, 16 semanas de treinamento aeróbio e resistido combinado em mulheres obesas na pós-menopausa é efetivo em aumentar a massa livre de gordura e reduzir adiposidade total e abdominal.

Palavras-chave: obesidade, treinamento de endurance, DEXA, climatério

Resumen - "Efecto del entrenamiento aeróbico y resistencia combinada en la composición corporal de mujeres posmenopáusicas obesas." El objetivo de este estudio fue investigar los efectos de 16 semanas de entrenamiento aeróbico y de resistencia combinada en la composición corporal en mujeres posmenopáusicas obesas. Los participantes fueron divididos en dos grupos: grupo de entrenamiento (GE, $n=37)$ y control $(\mathrm{C}, n=18)$. La grasa del tronco, la masa grasa, porcentaje de masa grasa y masa libre de grasa se utilizó el DXA. El recordatorio de 24 horas se realizó tres días no consecutivos para el control de los alimentos. El protocolo de entrenamiento consistió en 50 minutos de entrenamiento de resistencia, después 30 minutos de entrenamiento aeróbico. Después de 16 semanas de entrenamiento, no se observaron diferencias 
en la grasa del tronco $(C=0,064 \times \mathrm{GE}=-0,571 \mathrm{Kg} ; p$-valor= 0,020$)$, la masa grasa $(\mathrm{C}=-0,088 \times \mathrm{GE}=-1,037 \mathrm{Kg} ; p$-valor $=0,020 \mathrm{Kg})$ y libre de grasa $(\mathrm{C}=-0,388 \mathrm{x} \mathrm{GE}=1,049 \mathrm{Kg} ; p=0,001)$. Así, 16-semana de entrenamiento aeróbico y de resistencia combinada en las mujeres posmenopáusicas con obesidad es eficaz en la mejora de la masa libre de grasa y la disminución de la masa grasa y la adiposidad abdominal.

Palabras claves: obesidad, entrenamiento de la resistencia, DEXA, climaterio

\section{Introduction}

Epidemiological studies have identified that menopause promotes significant changes in body composition (Aubertin-Leheudre, Lord, Labonte, Khalil, \& Dionne, 2008; Day, Gozansky, Van Pelt, Schwartz, \& Kohrt, 2005; Donato, Fuchs, Oppermann, Bastos, \& Spritzer, 2006) and that postmenopausal women are at an increased risk of developing cardiovascular complications, such as endothelial dysfunction, stroke and cerebrovascular agents (Miller et al., 2013). Several scientific studies have suggested that some alterations in body composition (predominantly an increase in abdominal fat) play a central role in harmful events related to the postmenopausal period (Day et al., 2005; Donato et al., 2006; Huang, 2009).

Not only physiological aspects are related to increased cardiovascular risk during the postmenopausal period, but also unhealthy behaviors such as physical inactivity and inadequate diet which have been pointed out as complementary risk factors due to their strong relationship with weight gain (Ignarro, Balestrieri, \& Napoli, 2007). Buonani et al. (2013) reported that postmenopausal women, evaluated using a tri-axial accelerometer, who demonstrated higher values in minutes of moderate-vigorous physical activity ( $>150$ minutes/week) had lower levels of body fat (43.8 vs. 47. $2 \%$ ) and higher levels of lean body mass (53.8 vs.49.6 kg) compared to women who demonstrated less than 150 minutes/week.

The chronic effect of aerobic exercise is effective in the reduction/control of whole and central adiposity among postmenopausal women (Choquette et al., 2011; Friedenreich et al., 2011; Yassine et al., 2009), however, this kind of exercise is not enough for the preservation/maintenance of fat-free mass. On the other hand, resistance training is effective in improving muscle mass, but, in turn, its effectiveness in the reduction of body fat is unclear (Nelson et al., 2007).

Therefore, although the benefits of isolated aerobic and resistance training are well described in the literature (Bouchard, Soucy, Senechal, Dionne, \& Brochu, 2009; Choquette et al., 2011; Friedenreich et al., 2011; Hunter, McCarthy, \& Bamman, 2004; Nelson et al., 2007; Yassine et al., 2009), there is not enough information dealing with the effectiveness of a combination of both in the same session, (which is called combined training [CT]), to promote changes in body composition variables (improve both adiposity and fat-free mass simultaneously) and minimize the unhealthy effects of aging and the menopause. The hypothesis of our study was that combined training (aerobic plus resistance) would be effective in simultaneously decreasing whole and segmental fat mass and increasing fat-free mass in postmenopausal women.
The aim of this study was to verify the effects of 16-weeks of CT on body composition variables (whole and central adiposity) of postmenopausal women who are obese.

\section{Methods}

\section{Participants}

Adult women were invited through television and newspaper advertising to participate in the study. The participants contacted the researchers by phone and an appointment was made in order to carry out a more detailed interview. The inclusion/exclusion criteria were: 1 ) being in menopause (having had no menstrual cycle for at least one year and an FSH level of $30 \mathrm{U} /$ liter or greater) (WHO, 1996); 2) being obese (BM I $>29.9 \mathrm{Kg} / \mathrm{m}^{2}$ ), according to WHO (2004); 3) not presenting any physical limitations or health problems that could prevent the completion of the assessments and exercise intervention; 4) presenting a medical referral to participate in the training; 5) not having participated in any systematic physical exercise for, at least, six months prior to the study; 6) not receiving treatment for hormone replacement and 7) signing the consent form. The project was approved by the Ethics Research Group of the University (Protocol 64/2011).

The minimum sample size was estimated using data provided by a previous pilot study, which involved women with similar characteristics to the analyzed sample, as well as the same exercise protocol (body fatness mean difference: $-1.59 \mathrm{~kg}$ and standard-deviation $2.33 \mathrm{~kg}$ ). The pilot study's sample has not been included in this study. A power of $80 \%$ and two tailed test identified the necessity of at least 18 women in each group. In the sampling process, the allocation of the volunteers into the intervention and control groups was made using a random process. However, after both groups had reached the minimum sample size (including predicted losses), the additional volunteers were allocated only to the intervention group, due to the increased likelihood of drop outs.

Out of a total of 197 women who participated in the first screening, only 75 met all the inclusion criteria and agreed to participate in the study protocol. Participants were randomly distributed into two study groups: TG $(N=40)$ and CG $(N=$ 35 ). During the 16-weeks of intervention, 20 of the 75 women dropped out of the study (a dropout rate of 26.6\%). The reasons for drop outs included minor injury related to CT $(n=1)$, refusal of the 16-week post protocol testing $(n=6)$, personal/family problems $(n=3)$, unspecified reasons $(n=8)$, and accumulation of three consecutive absences or four nonconsecutive absences during one month $(n=2)$. The final sample was composed of 55 subjects who completed the 16-wks of the protocol, made up of the TG $n=37$ and the CG $n=18$ (Figure 1). 


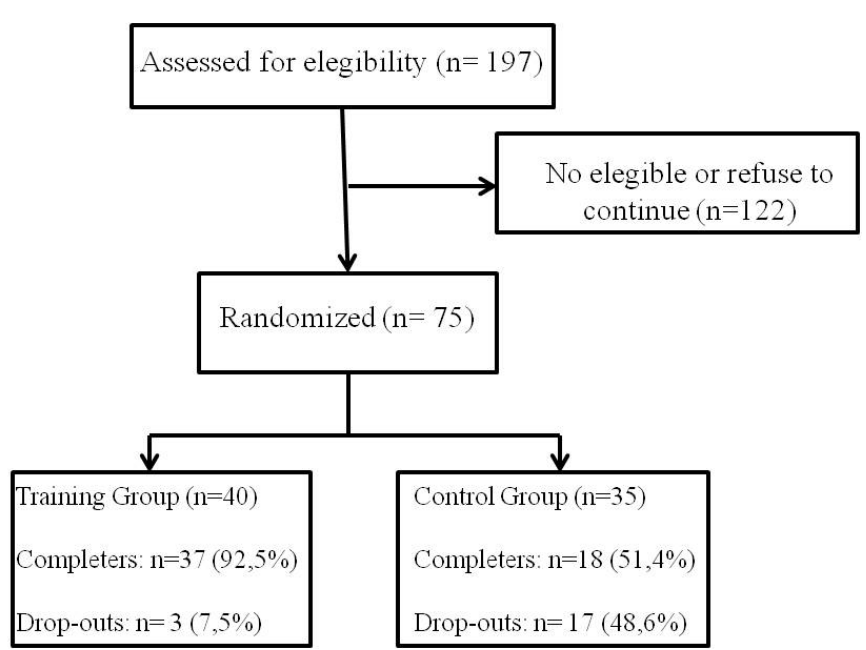

Figure 1. Trial profile of the 16 weeks of the study.

\section{Methods}

This intervention study was carried out from February to July of 2012 at São Paulo State University (UNESP), Presidente Prudente, Brazil. The initial assessment occurred two weeks before the baseline moment (M0) and consisted of the anamnesis to verify whether the participants met the inclusion criteria. During this period, anthropometry and body composition were evaluated. After 16-weeks of intervention all measurements were repeated (M16). The Training Group (TG) performed a 16-week intervention program of $\mathrm{CT}$ and the Control Group (CG) maintained 16 weeks of a sedentary lifestyle without participating in any regular physical exercise.

\section{Anthropometric measurements and body composition}

Anthropometry was composed of body weight and height measurements. Height was measured on a fixed stadiometer of the Sanny brand, with an accuracy of $0.1 \mathrm{~cm}$ and length of $2.20 \mathrm{~m}$. Body weight was measured using an electronic scale (Filizola PL 50, Filizzola Ltda., Brazil), with a precision of $0.1 \mathrm{~kg}$.

Whole and trunk fat (TF) were estimated using a Dual -Energy X-ray Absorptiometry (DXA) scanner, version 4.7 (General Electric Healthcare, Lunar DPX-NT; England). The subjects were positioned in a supine position and remained still throughout the examination. Fat mass (FM), fat-free mass (FFM) and trunk fat (TF) were assessed and expressed in absolute values by the DEXA software. The TF was estimated in the abdominal region, and was defined as $20 \%$ of the length from a circumference line at the pelvis to a circumference line at the neck (Bhupathiraju et al., 2011). All measurements were carried-out at the University laboratory, in a temperature controlled room. Each morning, before the beginning of the measurements, the equipment was calibrated by the same researcher, according to the manufacturer's instructions.

\section{Dietary record assessment}

Twenty-four hour dietary recalls were conducted on three nonconsecutive days (one weekend and two weekdays) (Thompson \& Byers, 1994). The participants were oriented by a nutritionist as to how to complete the dietary record. Data were analyzed by the same nutritionist using the software NutWin, version 1.5 (Programa de Apoio à Nutrição, Universidade Federal de São Paulo, Brazil, 2002).

\section{Exercise protocol}

CT was performed three times per week on non-consecutive days (approximately 90 minutes per day, comprised of five minutes of warm-up, 50 minutes of resistance training, 30 minutes of aerobic training and five minutes of stretching at the end). At the beginning of the activities there was a two-week period of familiarization to both the aerobic and the resistance exercises (the test of one maximum repetition occurred after two weeks of training familiarization). The exercises used in the program were: $45^{\circ}$ leg press, leg extension, leg curl, bench press, seated row, arm curl, triceps extension, side elevation with dumbbells and abdominal exercises.

\section{Aerobic exercise intensity}

The intensities of the aerobic training were established according to the anaerobic threshold (LAN) determined by the protocol of double not exhaustive efforts (Chassain, 1986)]. The training was performed on an official running track, marked every 50 meters. The initial intensity of training was $100 \%$ (1st to 4 th week) followed by $110 \%$ (5th to 8 th week) of the LAN performed pre-intervention. After eight weeks of training, a new test was performed to adjust the intensities. The intensity of the exercise was monitored through the time required to traverse each $400 \mathrm{~m}$ (1 lap), with the heart rate at around $70 \%$ of maximum heart rate (Mcardle et al., 2008). To ensure that the training speed was correct, the group was followed by professionals who monitored the speed of the training. Participants were instructed to drink water and wear appropriate clothes and shoes during training.

\section{Resistance training intensity}

The resistance training program consisted of four progressive phases [phase 1 ( 1 st to 4 th week, 15 repetitions at $\sim 65 \%$ of maximum, three sets per exercise, 60-90 sec between sets); phase 2 ( 5 th to 8 th week, 12 repetitions at $\sim 70 \%$ of maximum, three sets per exercise, $60-90 \mathrm{sec}$ between sets); phase 3 (9th to 12 th week, 10 repetitions at $\sim 75 \%$ of maximum, three to four sets per exercise, $60-90 \mathrm{sec}$ between sets) and phase 4 (13th to 16 th week, eight repetitions at $\sim 80 \%$ of maximum, three to four sets per exercise, 60-90 sec between sets)]. The training loads were adjusted every four weeks of training in order to maintain the number of repetitions prescribed (Table 1). 
Table 1. Aerobic training protocol.

\begin{tabular}{cc}
\hline Time session & Aerobic Training \\
\hline Week $1-4$ & $100 \%$ of the LAn pre-intervention \\
Week $5-8$ & $110 \%$ of the Lan pre-intervention \\
Week $9-12$ & $100 \%$ of the Lan post-eight weeks \\
Week $13-16$ & $110 \%$ of the Lan post-eight weeks \\
\hline
\end{tabular}

The intensity of the resistance training was controlled through the zone of maximum repetitions (MR). The series were executed until momentary exhaustion, meaning that, when participants performed the training with repetitions varying from 12 to $15 \mathrm{MR}$, they were always stimulated to execute at least 12 and no more than 15 repetitions (Silva, Gurjão, Ferreira, Gobbi, \& Gobbi, 2006). In the case of the participants executing more than 15 repetitions, the overload was increased in order to have the training zone respected (Silva et al., 2006). The test of one maximum repetition (1MR) was performed only in the leg press and bench press. The load was increased gradually during the test until the participants were unable to perform the entire movement, and three attempts were considered to meet the corresponding 1MR load (ACMS, 2006). To allow for recovery, an interval of 3 to 5 minutes was given between the attempts (ACMS, 2006).

\section{Data analysis}

The Kolmogorov-Smirnov test analyzed the data set distribution. All variables had normal distribution (significance $>.05$ ) and therefore, mean, standard-deviation and $95 \%$ confidence intervals were adopted as descriptive statistics. Initially, in order to identify the similarity of both groups at baseline (basic assumption), dependent variables were compared between the CG and TG using the Student $t$ test for independent samples. In the longitudinal analysis, dependent variables were treated as "mean differences" (post exercise value minus baseline value) and the Student $t$ test for independent samples was used once more to compare these mean differences between the CG and TG. Finally, the Spearman rank correlation (rho) was used to analyze the relationship between the mean differences of TF, FM and FFM and dietary intake.

All analyzes were performed using the statistical software BioEstat (version 5.0). The level of significance was set at 5\%.

\section{Results}

The mean age of the participants was $61.2 \pm 6.0$ (TG: $60.5 \pm 6.0$ and CG: $62.6 \pm 5.9 ; p$-value $=.230)$. At baseline, all variables were similar between the groups (Table 2).

After 16-wks of intervention, there were statistically significant differences between the TG group and the Control group, for $\mathrm{TF}(\mathrm{CG}=0.064[95 \% \mathrm{CI}=-0.06 ; 0.36]$ and $\mathrm{TG}=$ $-0.571[95 \% \mathrm{CI}=-0.99 ;-0.37] ; p$-value $=.020), \mathrm{FM}(\mathrm{CG}=-0.088$
$[95 \% \mathrm{CI}=-1.07 ; 0.54]$ and $\mathrm{TG}=-1.037[95 \% \mathrm{CI}=-1.83 ;-0.81]$; $p$-value $=.020)$ and FFM $(\mathrm{CG}=-0.388[95 \% \mathrm{CI}=-1.28 ;-0.11]$ and $\mathrm{TG}=1.049[95 \% \mathrm{CI}=0.57 ; 1.34] ; p=.001)$ (Figure 2$)$. When the changes in weight were analyzed, there were no significant differences observed between the groups.

Table 2. Resistance training protocol.

\begin{tabular}{lcccc}
\hline & Time session & \%1RM & Repetition & Interval \\
\hline Phase 1 & Week 1-4 & 65 & $3 \times 15$ & $60-90 \mathrm{sec}$ \\
Phase 2 & Week 5-8 & 70 & $3 \times 12$ & $60-90 \mathrm{sec}$ \\
Phase 3 & Week 9-12 & 75 & $3-4 \times 10$ & $60-90 \mathrm{sec}$ \\
Phase 4 & Week 13-16 & 80 & $3-4 \times 8$ & $60-90 \mathrm{sec}$ \\
\hline
\end{tabular}

$1 \mathrm{RM}=1$ repetition maximum; $60-90 \mathrm{sec}=60-90$ second of interval between sets.

A

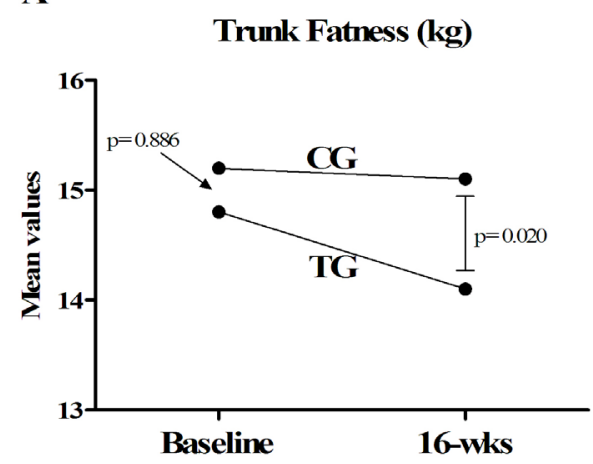

$\mathbf{B}$

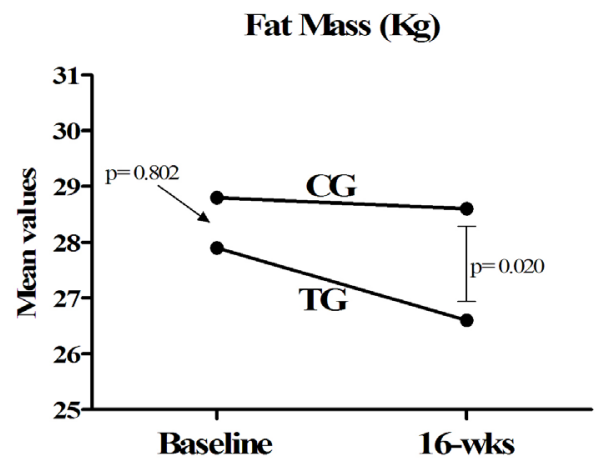

C

Fat Free Mass (Kg)

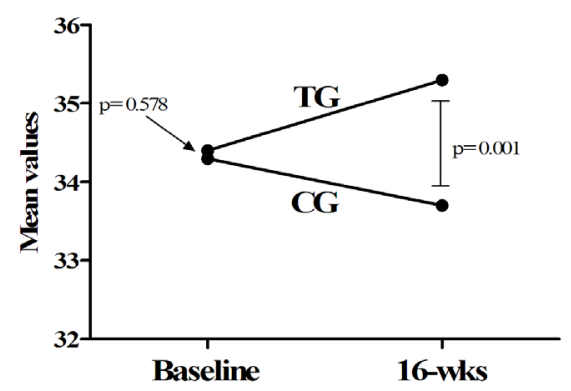

Figure 2. Absolute variation after the 16 weeks of intervention. $\mathrm{TG}=$ Training Group; $\mathrm{CG}=$ Control Group. 
Table 3. General characteristics of the sample at baseline (M0).

\begin{tabular}{lccc}
\hline & $\begin{array}{c}\text { Training Group } \\
(\boldsymbol{n}=\mathbf{3 7}) \\
\text { Mean (SD) }\end{array}$ & $\begin{array}{c}\text { Control Group } \\
(\boldsymbol{n}=\mathbf{1 8})\end{array}$ & $\boldsymbol{p}$-value \\
& Mean (SD) & \\
\hline Weight (kg) & $62.02(15.2)$ & $63.79(15.6)$ & .971 \\
TF (kg) & $14.85(5.5)$ & $14.63(7.5)$ & .886 \\
FM (kg) & $26.77(10.7)$ & $29.00(13.0)$ & .802 \\
FFM (kg) & $34.41(4.4)$ & $34.31(6.0)$ & .578 \\
\hline
\end{tabular}

$\mathrm{TF}=$ trunk fatness $; \mathrm{FM}=$ fat mass; $\mathrm{FFM}=$ fat free mass; $\mathrm{SD}=$ standard deviation.

Regarding dietary intake (expressed in kcal), after 16-wks of intervention, no differences were observed for the CG (Baseline $=1,615.2 \pm 345.9 \mathrm{Kcal}$ versus $16-\mathrm{wks}=1.660 .9 \pm 244.1 \mathrm{Kcal}$; $p=.552)$ or the TG (Baseline $=1,641.9 \pm 398.7 \mathrm{Kcal}$ versus 16$\mathrm{wks}=1,550.1 \pm 431.2 \mathrm{Kcal} ; p=.140)$. The values of the Spearman correlation between the mean differences in dietary intake and the composition variables are shown in Table 3. There was no significant relationship between dietary intake, whole and trunk fat and fat-free mass in either group analyzed.

\section{Discussion}

Previous studies have shown that long term aerobic exercise is effective in reducing FM in postmenopausal women, but changes in FFM have not been observed (Friedenreich et al., 2011; Lee et al., 2012; Wanderley et al., 2013). On the other hand, the isolated effect of resistance training on body composition in elderly women has shown an increase in FFM but without a decrease in FM (Binder et al., 2005).

In the present study, the combined training protocol was effective in both decreasing FM and increasing FFM. Endurance training improves the oxidative capacity and maximal oxygen uptake, and increases the activity of aerobic enzymes, intramuscular glycogen, mitochondrial and capillary densities in the muscles, but without leading to significant improvement in FFM (Chtara et al., 2005; Hakkinen et al., 2003). Additionally, resistance training is effective in increasing FFM and, in turn, muscle strength (Hunter et al., 2004). The biological mechanisms related to the effects of resistance training are supported by the recruitment of satellite cells, improvement in motor unit activations and increased high-energy phosphate availability (Hunter et al., 2004). Therefore, the presented protocol seems to be effective in this population, not only due to its benefits in the improvement of these two body composition components, but also for other unhealthy outcomes, such as osteoporosis and sarcopenia (Bemben \& Bemben, 2011; Hanson et al., 2009).

Obesity is related to the postmenopausal period and is also considered an important public health concern in different age groups (Bhuiyan \& Zaman, 2013; De Onis, Blossner, \& Borghi, 2010; Ghorbani, Ziaee, Oveisi, \& Afaghi, 2013), as it affects a large variety of biological systems and is responsible for an increasing number of chronic diseases (Whitcroft \& Herriot, 2011). After the postmenopausal period there are significant changes in body composition, with a decrease in fat-free mass $(\sim 3.0 \mathrm{~kg})$, an increase in fat mass $(\sim 2.5 \mathrm{~kg})$ and a decrease in resting metabolic rate $(\sim 100$ kilocalories per day) (Poehman et al., 1995; Poehman, 2002). Toth et al. (2000) examined the effects of the menopausal status on body composition and abdominal fat distribution in 53 middle-aged, premenopausal and postmenopausal women and observed that the postmenopausal women had 36\% more trunk fat $(p<.01)$, a $49 \%$ greater intra -abdominal fat area $(p<.01)$, and a $22 \%$ greater subcutaneous abdominal fat area $(p<.05)$ than the premenopausal women. In addition to excessive body fatness, scientific literature has identified that, abdominal adipose tissue has neuroendocrine characteristics, which are related to metabolic and cardiovascular implications (Van Gaal, Mertens, \& De Block, 2006).

Similar to our findings, previous studies have identified that abdominal adipose tissue in postmenopausal women is affected by aerobic exercise (Friedenreich et al., 2011). Another study observed similar results in women aged 39 to 64, after 21-weeks of combined exercise (resistance training and aerobic exercise applied on different week days) (Sillanpää et al., 2009), identifying that this protective effect on abdominal obesity is also observed in other age groups and could be used to explain the effect of the combined training on the metabolic syndrome components in women aged 40 years (Seo et al., 2010). In general, responses to acute exercise suggest that higher-intensity exercise may be more effective than low-to-moderate-intensity exercise for inducing the secretion of lipolytic hormones, facilitating greater post-exercise energy expenditure and fat oxidation (Pritzlaff et al., 2000).

Dietary habits are significantly related to body composition modifications and thus, modifications in dietary intake during the exercise protocol could affect the analyzed outcomes (Faria, Faria, Buffington, De Almeida Cardeal, \& Ito, 2011). However, in this sample, there was no significant relationship between modifications in diet and body composition, which decreases the likelihood of this kind of bias related to dietary modifications.

The present study showed some benefits of combined training on the whole and segmental body composition variables, but other studies must be done to verify the effect of this exercise protocol on other variables, such as metabolic and hemodynamic. Furthermore, there was no isolated aerobic or resistance groups for better comparison.

However, if the purpose is the improvement of maximal strength, muscle power and performance, some care in the prescription of training programs is necessary (Leveritt, Abernethy, Barry, \& Logan 1999). In this case, an interesting alternative would be for aerobic and resistance training to be done on nonconsecutive days, as well as other strategies discussed in the review by Paulo et al. (2005).

In conclusion, the combination of aerobic and resistance training in the same session, over a relatively short period of systematic training, was effective in improving FFM and decreasing whole and segmental fat mass in obese postmenopausal women and could be a useful strategy for improving health status and preventing some disorders related to sedentary habits as well as minimizing some of the side effects of aging. Furthermore, it may be an effective non-pharmacological strategy in the prevention and treatment of obesity, thereby decreasing drug intake. 


\section{References}

American College of Sports Medicine. KaminskyL, editor. (2006). ACSM's guidelines for exercise testing and prescription. 7th ed. Baltimore: Lippincott, Williams \& Wilkins.

Aubertin-Leheudre, M., Lord, C., Labonte, M., Khalil, A., \& Dionne, I.J. (2008). Relationship between sarcopenia and fracture risks in obese postmenopausal women. Journal of Women \& Aging, 20, 297-308. dói: 10.1080/08952840801984964

Bemben, D.A., \& Bemben, M.G. (2011). Dose-response effect of 40 weeks of resistance training on bone mineral density in older adults. Osteoporosis International, 22, 179-186. dói: 10.1007/s00198-010-1182-9

Bhuiyan, M.U., Zaman, S., \& Ahmed, T. (2013). Risk factors associated with overweight and obesity among urban school children and adolescents in Bangladesh: a case-control study. BMC Pediatrics, 13, 72. doi:10.1186/1471-2431-13-72

Binder, E.F., Yarasheski, K. E., Steger-May, K., Sinacore, D.R., Brown, M., Schechtman, K.B., \& Holloszy, J.O. (2005). Effects of Progressive Resistance Training on Body Composition in Frail Older Adults: Results of a Randomized, Controlled Trial. Journal of Gerontology Series A: Biological Sciences and Medical Sciences, 60, 1425-1431. dói: $10.1093 /$ gerona/60.11.1425

Bouchard, D.R., Soucy, L., Senechal, M., Dionne, I.J., \& Brochu, M. (2009). Impact of resistance training with or without caloric restriction on physical capacity in obese older women. Menopause, 16, 66-72. dói: 10.1097/gme.0b013e31817dacf7

Bhupathiraju, S.N., Dawson-Hughes, B., Hannan, M.T., Lichtenstein, A.H., \& Tucker, K.L. (2011). Centrally located body fat is associated with lower bone mineral density in older Puerto Rican adults. The American Journal of Clinical Nutrition, 94, 1063-1070. dói: 10.3945/ajen.111.016030

Buonani, C., Rosa, C.S.D.C., Diniz, T.A., Christofaro, D.G.D., Monteiro, H.L., Rossi, F.E., \& Freitas Júnior, I.F. (2013). Physical activity and body composition in menopausal women. Revista Brasileira de Ginecologia e Obstetrícia, 35, 153-158.

Chassain, A. (1986). Methode d appreciation objective de la tolerance de l' organism á 1 effort: application á la mensure des puissances de la frequence cardiaque et de la lactatemie [A method for objective evaluation of body tolerance to effort applied to measurement of critical peaks in heart rate and lactatemia]. Science \& Sports, 1, 41-44. dói: 10.1016/S0765159786800739

Choquette, S., Riesco, E., Cormier, E., Dion, T., Aubertin-Leheudre, M., \& Dionne, I.J. (2011). Effects of soya isoflavones and exercise on body composition and clinical risk factors of cardiovascular diseases in overweight postmenopausal women: a 6-month double-blind controlled trial. The British Journal of Nutrition, 105, 1199-1209. dói: 10.1017/S0007114510004897

Chtara, M., Chamari, K., Chaouachi, M., Chaouachi, A., Koubaa, D., Feki Y., ...Amri, M. (2005). Effects of intra-session concurrent endurance and strength training sequence on aerobic performance and capacity. British Journal of Sports Medicine, 39, 555-560. dói: 10.1136/bjsm.2004.015248

Day, D.S., Gozansky, W.S., Van Pelt, R.E., Schwartz, R.S., \& Kohrt, W.M. (2005). Sex hormone suppression reduces resting energy expenditure and \{beta\}-adrenergic support of resting energy expenditure. The Journal of Clinical Endocrinology and Metabolism, 90, 3312-3317. dói: 10.1210/jc.2004-1344

De Onis, M., Blossner, M., \& Borghi, E. (2010). Global prevalence and trends of overweight and obesity among preschool children. The American Journal of Clinical Nutrition, 92, 1257-1264. dói: 10.3945/ajen.2010.29786

Donato, G.B., Fuchs, S.C., Oppermann, K., Bastos, C., \& Spritzer, P.M. (2006). Association between menopause status and central adiposity measured at different cutoffs of waist circumference and waist-to-hip ratio. Menopause, 13, 280-285. dói: 10. 1097/01. gme.0000177907.32634.ae

Faria, S.L., Faria, O.P., Buffington, C., De Almeida Cardeal, M., \& Ito, M.K. (2011). Dietary protein intake and bariatric surgery patients: a review. Obesity Surgery, 21, 1798-1805. dói: 10.1007/ s11695-011-0441-y

Fernandes, R.A., \& Zanesco, A. (2010). Early physical activity promotes lower prevalence of chronic diseases in adulthood. Hypertension Research, 33, 926-931. dói: 10.1038/hr.2010.106

Friedenreich, C.M., Woolcott, C.G., McTiernan, A., Terry, T., Brant, R., Ballard-Barbash, ...Courneya, K.S. (2011). Adiposity changes after a 1-year aerobic exercise intervention among postmenopausal women: a randomized controlled trial. International Journal of Obesity, 35, 427-435. dói: 10.1038/ijo.2010.147

Ghorbani, A., Ziaee, A., Oveisi, S., \& Afaghi, A. (2013). A Comparison of Health-Related Quality of Life among Normal-Weight, Overweight and Obese Adults in Qazvin Metabolic Diseases Study (QMDS), Iran. Global Journal of Health Science, 5, 156-162. dói: 10.5539/gjhs.v5n3p156

Hakkinen, K., Alen, M., Kraemer, W. J., Gorostiaga, E., Izquierdo, M., Rusko, H., ... Paavolainen L. (2003). Neuromuscular adaptations during concurrent strength and endurance training versus strength training. European Journal Applied Physiology, 89, 42-52. dói: 10.1007/s00421-002-0751-9

Hanson, E.D., Srivatsan, S.R., Agrawal, S., Menon, K.S., Delmonico, M.J., Wang, M.Q., \& Hurley, B.F. (2009). Effects of strength training on physical function: influence of power, strength, and body composition. Journal of Strength and Conditioning Research, 23, 2627-2637. dói: 10.1519/JSC.0b013e3181b2297b

Huang, P.L. (2009). eNOS, metabolic syndrome and cardiovascular disease. Trends in Endocrinology and Metabolism, 20, 295-302. dói: 10.1016/j.tem.2009.03.005

Hunter, G.R., McCarthy, J.P., \& Bamman, M.M. (2004). Effects of resistance training on older adults. Sports Medicine, 34, 329-348.

Ignarro, L.J., Balestrieri, M.L., \& Napoli, C. (2007). Nutrition, physical activity, and cardiovascular disease: an update. Cardiovascular Research, 73, 326-340. dói: 10.1016/j.cardiores.2006.06.030

Lee, S., Bacha, F., Hannon, T., Kuk, J.L., Boesch, C., \& Arslanian, S. (2012). Effects of aerobic versus resistance exercise without caloric restriction on abdominal fat, intrahepatic lipid, and insulin sensitivity in obese adolescent boys: a randomized, controlled trial. Diabetes, 61, 2787-2795. dói: 10.2337/db12-0214

Leveritt, M., Abernethy, P.J., Barry, B.K., \& Logan, P.A. (1999). Concurrent strength and endurance training. A review. Sports medicine, 28, 413-427.

Mcardle, W.D., Katch, F.I., \& Katch, V.L. (2008). Exercise Physiology Energy, Nutrition and Human Performance. Rio de Janeiro: Koogan.

Miller, V.M., Garovic, V.D., Kantarci, K., Barnes, J.N., Jayachandran, M., Mielke, M. M, ... Rocca, W.A. (2013). Sex-specific risk of cardiovascular disease and cognitive decline: pregnancy and menopause. Biology of Sex Differences, 4, 6. dói: 10.1186/2042-6410-4-6

Nelson, M.E., Rejeski, W.J., Blair, S.N., Pamela, W., Duncan, P.W., James, J.O., ... Castaneda-Sceppa, C. (2007). Physical activity and public health in older adults: recommendation from the American College of Sports Medicine and the American Heart Association. Circulation, 116, 1094-1105. dói: 10.1249/mss.0b013e3180616aa2

Organización Mundial De La Salud. (1996). Investigaciones sobre la menopausia en los años noventa. Genebra: Organización Mundial de la Salud.

Paulo, A.C., de Souza, E.O., Laurentino, G., Ugrinowitsch, C., \& Tricoli, V. (2009). Efeito do treinamento concorrente no desenvolvimento da força motora e da resistência aeróbia. Revista Mackenzie de Educação Física e Esporte,4. 
Poehlman, E.T., Toth, M.J., \& Gardner, A.W. (1995). Article RETRACTED: Changes in Energy Balance and Body Composition at Menopause: A Controlled Longitudinal Study. Annals of Internal Medicine, 123, 673-675.

Poehlman, E.T. (2002). Menopause, energy expenditure, and body composition. Acta obstetricia et gynecologica Scandinavica, 81, 603-611.

Pritzlaff, C.J., Wideman, L., Blumer, J., Jensen, M., Abbott, R.D., Gaesser, G.A., ... Weltman, A. (2000). Catecholamine release, growth hormone secretion, and energy expenditure during exercise vs. recovery in men. Journal of Applied Physiology, 89, 937-946.

Seo, D.I., Jun, T.W., Park, K.S., Chang, H.K., So, W.Y., \& Song, W. (2010). 12 weeks combined exercise training is better than aerobic exercise for increasing Growth Hormone in middle-aged women. International Journal of Sport Nutrition and Exercise Metabolism, 20, 21-26.

Silva, C.M., Gurjão, A.L.D., Ferreira, L., Gobbi, L.T.B., \& Gobbi, S. (2006). Efeito do treinamento com pesos, prescrito por zona de repetições máximas, na força muscular e composição corporal em idosas. [Effect of resistance training, prescribed by zone of maximum repetitions, on the muscular strength and body composition in older women]. Revista Brasileira de Cineantropometria e Desempenho Humano, 8, 39-45.

Sillanpää, E., Laaksonen, D.E., Karavirta, A.H.L., Jensen, B., Kraemer, W.J., Nyman, K., \& Häkkinen, K. (2009). Body composition, fitness, and metabolic health during strength and endurance training and their combination in middle-aged and older women. European Journal of Applied Physiology, 106, 285-296. dói: 10.1007/ s00421-009-1013-x

Toth, M.J., Tchernof, A., Sites, C.K., \& Poehlman, E.T. (2000). Menopause-related changes in body fat distribution. Annals of the New York Academy of Sciences, 904, 502-506.

Thompson, F., \& Byers, T. (1994). Dietary assessment resource manual. The Journal of Nutrition, 124, 2245S-317S.

Van Gaal, L.F., Mertens, I.L., \& De Block, C.E. (2006). Mechanisms linking obesity with cardiovascular disease. Nature, 444, 875-880. dói: 10.1038/nature05487

Wanderley, F.A., Moreira, A., Sokhatska, O., Palmares, C., Moreira, P., Sandercock, G., ... Carvalho, J. (2013). Differential responses of adiposity, inflammation and autonomic function to aerobic versus resistance training in older adults. Experimental Gerontology, 48, 326-333. dói: 10.1016/j.exger.2013.01.002

Whitcroft, S., \& Herriot, A. (2011). Insulin resistance and management of the menopause: a clinical hypothesis in practice. Menopause International, 17, 24-28. dói: 10.1258/mi.2011.011003

WHO. World Health Organization Consequences of overweight and obesity on the health of adults and children. In: WHO. Obesity Preventing and Controlling Global Epidemic. 1. Ed. Sao Paulo: ROCA, 2004.

Yassine, H.N., Marchetti, C.M., Krishnan, R.K., Vrobel, T.R., Gonzalez, F., \& Kirwan, J.P. (2009). Effects of exercise and caloric restriction on insulin resistance and cardiometabolic risk factors in older obese adults--a randomized clinical trial. Journal of Gerontology Series A: Biological Sciences and Medical Sciences, 64, 90-95.

\section{Authors'note}

Fabrício E. Rossi, Tiego A. Diniz, and Vanessa R. dos Santos are affiliated with the Institute of Bioscience, São Paulo State University, Rio Claro, São Paulo, Brazil.

Camila Buonani, Juliana Viezel, Eduardo P. da Silva, Rômulo A. Fernandes, and Ismael F. Freitas Junior are affiliated with the Department of Physical Education, São Paulo State University, Presidente Prudente, São Paulo, Brazil.

\section{Corresponding author}

Fabrício E. Rossi

Department of Physical Education, Universidade Estadual Paulista "Júlio Mesquita Filho", Roberto Simonsen Street, no 305, Educational Center, Presidente Prudente, 19060-900, São Paulo, Brazil.

Telephone: 551832295828 Fax. 551832214391.

e-mail: rossifabricio@yahoo.com.br

\section{Conflict of interest}

The authors declare that they have no conflict of interest.

Manuscript received on March 25, 2014

Manuscript accepted on January 30, 2015

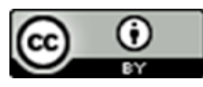

Motriz. The Journal of Physical Education. UNESP. Rio Claro, SP, Brazil - eISSN: 1980-6574 - under a license Creative Commons - Version 3.0 